\title{
Islam and Politics in Indonesia
}

\author{
Refly Setiawan, Melinda Esti, Viktor V. Sidorov \\ Kazan Federal University \\ 18, Kremlevskaya St, Kazan, 420008, Russian Federation \\ refly@ubl.ac.id, viktor.sidorov@kpfu.ru \\ Bandar Lampung University \\ 29, Labuhan Ratu, Kec. Kedaton, Kota Bandar Lampung, Lampung, 35142, Indonesia \\ estimelinda1987@gmail.com
}

\begin{abstract}
The Republic of Indonesia is characterized by ethnic and religious diversity. Islam is the most widespread religion in Indonesia and most of the Indonesian population is Muslim. Indonesian society is based on the principles of religious tolerance. The equality of people is the most important socio-political value of the Indonesian society, which guarantees an equality for allpeople, regardless of their ethnicity, religion or social class. Religion can be the foundation that can strengthen the country and become the foundation for development. At the same time, religion may not be the official state ideology. We study the relationship between religion and state in Indonesia. What problems arise in the relationship between religion and the state? This study aims to find out how Islam and politics in Indonesia are in harmony with the ideology of the Indonesian nation and how religious values can support moral foundations of Indonesian politics. We used analyze secondary sociological data and studied researches of the largest Indonesian academics on the problems of the relationship between religion and politics. We used the method of library research with abstracting and collecting data. A new set of scientific sources in the Indonesian language is being introduced into scientific circulation. The results of the study showed that Indonesia is not a democracy based on the principles of democratic processes of Western Europe. The peculiarity of Indonesia lies in the interaction of religious values and the politics. Indonesian politics is characterized by religious tolerance. At the same time, religious and cultural values are incorporated into the political practices of Indonesia in the form of moral and ethical guidelines. Thus, Indonesia is not a religious or secular country, but a country where religious values are the moral and ethical main ideology of state development.
\end{abstract}

Keywords: Islam, religion, ideology, Indonesia, Indonesian politics, religious tolerance

Article history: Submitted on 01.08.2020. Accepted on 10.08.2020.

For citation: Setiawan R., Esti M., Sidorov V.V. Islam and Politics in Indonesia. RUDN Journal of Political Science. 2020; 22 (4): 731-740. DOI: 10.22363/2313-1438-2020-22-4-731-740

(C) Setiawan R., Esti M., Sidorov V.V., 2020

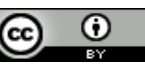

This work is licensed under a Creative Commons Attribution 4.0 International License https://creativecommons.org/licenses/by/4.0/ 


\title{
Ислам и политика в Индонезии
}

\author{
Р. Сетиаван, М. Эсти, В.В. Сидоров \\ Казанский федеральный университет \\ Российская Федераиия, 420008, Казань, ул. Кремлевская, 18 \\ refly@ubl.ac.id, viktor.sidorov@kpfu.ru \\ Университет Бандар Лампунг \\ Индонезия, 35142, Лампунг, Кота-Бандар-Лампунг, Кек. Кедатон, Лабухан Рату, 29 \\ estimelinda1987@gmail.com
}

\begin{abstract}
Аннотация. Республика Индонезия характеризуется большим этническим и религиозным разнообразием. Ислам - самая распространенная религия в Индонезии, и большая часть населения Индонезии исповедует ислам. Индонезийское общество основывается на принципах религиозной толерантности. Равенство людей является важнейшей социально-политической ценностью индонезийского общество, гарантирующей равное отношение государства к гражданам, независимо от принадлежности к этнической группе, религиозной общности или социальному классу. Религия может стать фундаментом, способным укрепить страну и стать основой для развития. При этом религия может и не быть официальной государственной идеологией. Как строятся взаимоотношения религии и государства в Индонезии? Какие проблемы возникают во взаимоотношении религии и государства? Исследование направлено на выяснение того, насколько ислам и политика в Индонезии находятся в гармонии с идеологией индонезийской нации и как религиозные ценности могут поддерживать мораль в индонезийской политике. Мы использовали метод сбора вторичных социологических данных и исследовали работы крупнейших индонезийских исследователей по проблемам взаимоотношения религии и политики, а также метод библиотечного исследования, который представляет собой реферирование и сбор данных. В научный оборот вводится новая совокупность научных источников на индонезийском языке. Результаты исследования показали, что Индонезия не является демократией, основанной на принципах демократических процессов, характерных для Западной Европы. Особенность Индонезии заключается во взаимодействии религиозных ценностей и политической сферы. Индонезийская политика характеризуется религиозной толерантностью. При этом религиозные и культурные ценности инкорпорируются в политические практики Индонезии в форме морально-нравственных ориентиров. Таким образом, Индонезия - это не религиозная или светская страна, а страна, где религиозные ценности являются морально-нравственной основой идеологии развития государства.
\end{abstract}

Ключевые слова: ислам, религия, идеология, Индонезия, индонезийская политика, религиозная толерантность

История статьи: Поступила в редакцию 01.08.2020. Принята к публикации 10.08.2020.

Для цитирования: Setiawan R., Esti M., Sidorov V.V. Islam and Politics in Indonesia // Вестник Российского университета дружбы народов. Серия: Политология. 2020. Т. 22. № 4. С. 731-740. DOI: $10.22363 / 2313-1438-2020-22-4-731-740$

\section{Introduction}

Indonesia is one of the countries with the largest Muslim population in the world and in the midst of the life of the majority of the Muslim community, they have a viewpoint related to state, nationality and society that is not based on a religious understanding [1]. The Republic of Indonesia has an ideology called 
Pancasila which means five principles. The five principles include; One Godhead, just and civilized humanity, Indonesian unity, wisdom led by wisdom in representative deliberations, and social justice for all Indonesians. In the context of state life, Pancasila is not only the ideology of the nation but also the basis of the Indonesian State [2].

The realization of the Pancasila agreement as the basis of the State in the process through critical times and almost threatens the nation's rift, but these differences can be met because the Indonesian people prioritize national unity and integrity [3]. The acceptance of Pancasila as the ideology of the Republic of Indonesia has a very clear influence on the policies and the continuity of the national values and religious teachings of the Indonesian people [4]. Indonesia with a majority Muslim population causes Islam to continue to play its role in accordance with social and political processes even though this role is shown in the government system of the Republic of Indonesia. In the social and political dynamics in Indonesia, it provides opportunities for Islamic politics to easily win competition in political parties [5].

Discussions about Islam and politics or religion and the state are very interesting and never tired to discuss, especially after the development of secular political thought in the Islamic world, including in Indonesia. The discussion about Islam and politics has increasingly surfaced after the abolition of the Ottoman Caliphate system by Mustafa Kemal Ataturk on March 3, 1924 and was followed by the revocation of Islam as the official state religion and the elimination of the country's highest source of law. Mustafa Kemal's separation of religion and state in Istanbul is a manifestation of his strong desire to follow and adopt secular political thought from Western Europe with his main grand theory of Max Weber [6]. Secularism is something that is considered good by western nations because historically western nations were born from resistance to the influence of church thought in the Middle Ages.

Religion and state are still problematic in Indonesia. The issue of religion and the state aims to present the role of Islam within the scope of the Republic of Indonesia. When the Government of the Republic of Indonesia attempts to revise the Constitution of the Republic of Indonesia, problems arise regarding the choice to be taken by the government, namely the Pancasila Ideology or Islam [7]. In this case, it gave rise to a very strong political interest from secular nationalists and Islamic nationalists which eventually resulted in a political compromise with the issuance of the Presidential Decree of the Republic of Indonesia which reaffirmed the 1945 Constitution [8]. In the period after the independence of the Republic of Indonesia, Islam tended to be seen as extreme and did not seem to support the Pancasila ideology [9]. This extreme impression reappeared during the current era of Indonesian President Joko Widodo. This is because the religion of Islam is often associated with political party movements which tend to cause conflicts between religious communities so that the government tries to prevent divisions between nations.

This research is a reality which explains that there is an inability of the government to discuss a secular vision with a vision that wants religion on the basis of the state so that the state in political reality seems to deviate from religious ethics 
and morality. Political development in Indonesia shows that religion is the most important political institution in the government system [10]. Through religion, politicians in Indonesia try to focus their attention in seeking power, either directly or indirectly. In Indonesia, religion is used as a source of reference in making decisions relating to the interests of the Indonesian people themselves [11].

To find out about Islam and politics or religion and the state in Islamic political thought in Indonesia, it is necessary to study the political views and attitudes or political thoughts of prominent Muslims in Indonesia as well as various sources that can be used as a basis for thinking about Islam and the State in Indonesia. Their views are considered to represent thoughts and explain various problems not only concerning religious issues but also in other matters relating to the Republic of Indonesia.

\section{Research methods}

This type of research is library research, which is a series of studies relating to the method of collecting library data, or research where the object of research is explored through a variety of library information (books, encyclopedias, scientific journals, newspapers, magazines, and documents). Literature research or literature review is research that critically examines or reviews the knowledge, ideas, or findings contained in the academic-oriented literature, and formulates theoretical and methodological contributions to certain topics [11].

The focus of library research is to find various theories, laws, propositions, principles, or ideas that are used to analyze and solve the research questions formulated. This research is a descriptive analysis, which describes regularly the data that has been obtained, then it is given an understanding and explanation so that it can be understood properly by the reader.

The data used in this research is secondary data. Secondary data is data obtained not from direct observation. However, these data were obtained from the results of research that had been conducted by previous researchers. The secondary data sources are in the form of books and primary or original scientific reports contained in articles or journals (printed and / or non-printed) relating to the history of Islam and politics in Indonesia. Source selection is based on four aspects, namely [12]: (1) Provenance (evidence), namely aspects of the author's credentials and evidence support, for example the main source of history; (2) Objectivity, namely whether the perspective idea from the author has many uses or is it detrimental; (3) Persuasiveness (degree of confidence), namely whether the author is a person who can be trusted; and (4) Value (contributive value), namely whether the author's argument is convincing, and has a significant contribution to other research.

\section{Research results and discussion}

\section{Islam and Politics in Indonesia}

Islam and politics are two things that are difficult to separate in the Unitary State of the Republic of Indonesia. This is because the majority of Indonesians are Muslim and uphold Islamic values in their daily lives. In political activities, 
Indonesian society refers to Islamic values and tends to mix religious values into various political activities. Islam is the largest religion in the Republic of Indonesia which is closely related to the history of the development of Islam in Indonesia and the rapid spread of Islam [14]. Currently, there are many political parties in Indonesia that carry Islamic values and have Islamic nuances. The history of the development of political parties in Indonesia dates back to the Dutch colonial period in Indonesia, which caused the Indonesian nation to integrate religious values into politics in Indonesia. Since the struggle for independence of the Indonesian nation, many Indonesian heroes who spread Islamic values until after achieving independence the Indonesian nation continued to spread religious values in Indonesian politics [15].

In the Indonesian context, the relationship between Islam and politics has also become clear in the acceptance of Pancasila as the only ideology of the Indonesian nation. This does not mean eliminating Islamic ideals and eliminating Islamic elements in Indonesian politics. In this case, the extent to which the elements of the Islamic religion are considered capable of providing inspiration in political parties, depends on the extent to which Muslims in Indonesia are considered capable of coming up with new styles that can develop a wealth of social and political knowledge to map and analyze social transformation [16].

The relationship between religion and politics in general can be seen and observed from the position of religion and its role in community life [17]. According to Nurcholish Madjid, religion has a central position in a person's life because religion provides the general purpose of life and helps focus its energies in pursuing these goals. If someone believes that religion is not just a role model [18]. According to Munawir [19], the concept of Indonesia as a country with the Pancasila ideology must be maintained and guarded, however, the concept of Indonesia as an Islamic State has clearly been rejected by all Indonesians because Indonesia is not an Islamic State but Indonesia is a country with a majority of the population who are Muslim and apply Islamic values, religious values in everyday life.

Problems regarding the relationship between Islam and the Indonesian state actually center around the different views of political figures in Indonesia [20]. Secular politics which is becoming a trend in Western Europe are faced with the views of political figures in Indonesia who prioritize the values of Pancasila as the nation's ideology. This is because the founding figures of the Republic of Indonesia have made a boundary in politics in Indonesia and it seems that today the relationship between Islam and the Indonesian state is still possible by adjusting the ideological values of the Indonesian nation [21]. According to Nurcholish Madjid, the adjustment of religious values and ideology is a concrete form of the relationship between Islam and the Indonesian state based on the Pancasila Ideology and an indicator of the appreciation of the Indonesian political system for a civilizational identity [18].

The Indonesian political system doesn't completely adopt the basic assumptions of modern politics that are trending in North America and Western Europe, but rather adopts cultural and religious values that exist in Indonesia. In 
this context, Islamic Neo-Modernists view democracy as the most appropriate political rule, while religion is positioned as a moral regulatory tool in applying democracy [16]. In the relationship between Islam and democracy in Indonesia, there are two problems faced, namely, the first is a philosophical problem, namely, if the claim of religion to its adherents as a whole can shift the economy and independence of the Indonesian nation, which means that this can also change the principles of democracy in Indonesia. The two historical sociological problems are when in fact the role of religion is often used by the authorities to support their political interests and can destroy the democratic system in Indonesia [22].

According to Abdurrahman Wahid [8], there are democratic values that are basic and some are derivative or continuation of the main ones. According to him, there are three main values of democracy, namely, justice, freedom and deliberation. Justice is the foundation of democracy and an opportunity for all people to organize their lives according to their wishes. Freedom that is meant is individual freedom before the power of the State or individual rights as citizens and collective rights of the community, while deliberation is a form of maintaining freedom and fighting for justice through deliberation. The idea of democracy basically adheres to the basis of human equality so that individual rights can be guaranteed freedom [23]. According to Nurcholish Madjid, a democratic value can refer to a nation's ideology and not only because of considerations in principle, namely because democratic values are justified and supported by the spirit of Islamic teachings, but also because of their function as rules of an open political game and in accordance with values - Values of Indonesian ideology [18].

\section{Religion and Political Parties in Indonesia}

The Republic of Indonesia is the largest archipelagic country in the world where there are various ethnic groups, languages and religions. The Government of the Republic of Indonesia officially only recognizes six religions, namely Islam, Protestantism, Catholicism, Hinduism, Buddhism and Confucianism. The majority of Indonesia's population is Muslim and is spread across various islands in Indonesia, such as Java, Bali, Sumatra and Kalimantan. Currently there are more than 207 million Muslims in Indonesia who live side by side with other religions [24]. People in Indonesia are known for their high levels of tolerance and mutual respect, so it cannot be denied that in political parties in Indonesia, not only Islam but also other religions such as Christianity, Hinduism and Buddhism are involved in political activities. The Muslim community cooperates with other religions to seize power in politics in Indonesia by forming coalitions with non-Muslim majority political parties.

In Indonesia, religion is a very important thing in state life, this is because the majority of people in Indonesia want a leader who applies religious values and is able to maintain the integrity of the nation from divisions and conflicts between religions in Indonesia. Religion is considered to be able to build harmony in the life of various communities in Indonesia. The mutual respect between Muslim and non- 
Muslim communities is a reflection that the Indonesian nation accepts various religions that are recognized in this country [11;19].

At this time in Indonesia there are still many political parties that still adhere to religious values and apply them in political activities. The following are various political parties that are officially recognized in Indonesia and apply religious values that are in line with the principles of the Pancasila Ideology (table 1).

Table 1

Political Party in Indonesia

\begin{tabular}{|c|c|c|c|}
\hline No. & Names of Political Parties & Acronym & Party Status \\
\hline 1. & National Awakening Party & PKB & National \\
\hline 2. & Great Indonesia Movement Party & GERINDRA & National \\
\hline 3. & $\begin{array}{l}\text { Indonesian Democratic Party of } \\
\text { Struggle }\end{array}$ & PDIP & National \\
\hline 4. & Party of Work Group & GOLKAR & National \\
\hline 5. & NASDEM Party & Nasional Demokrat & National \\
\hline 6. & Indonesian Change Movement Party & GARUDA & National \\
\hline 7. & Party Work & BERKARYA & National \\
\hline 8. & Prosperous Justice Party & PKS & National \\
\hline 9. & Indonesian Unity Party & PERINDO & National \\
\hline 10. & United Development Party & PPP & National \\
\hline 11. & Indonesian Solidarity Party & PSI & National \\
\hline 12. & National Mandate Party & PAN & National \\
\hline 13. & People's Conscience Party & HANURA & National \\
\hline 14. & Democratic Party & PD & National \\
\hline 15. & Aceh Party & PA & Local \\
\hline 16. & SIRA Party & SIRA & Local \\
\hline 17. & Aceh Regional Party & PD Aceh & Local \\
\hline 18. & Nanggroe Aceh Party & PNA & Local \\
\hline 19. & Moon Star Party & PBB & National \\
\hline 20. & Indonesian Justice and Unity Party & PKP & National \\
\hline
\end{tabular}

Source: Republic of Indonesia Election Commission Online Portal (data processed).

Politics in Indonesia with a multi-party system allows people in Indonesia to be easily involved in political party activities as they wish. Most people see political parties based on their track record and involvement in development in Indonesia. Currently, the largest Islamic party in Indonesia is the Prosperous Justice Party (PKS) and the National Awakening Party (PKB) which are the driving force for the Muslim community in Indonesia. However, not only the Prosperous Justice Party (PKS) and the National Awakening Party (PKB), but also other parties have party followers who are predominantly Muslim. Political activities in Indonesia sometimes tend to be associated with Islamic movements which are of extreme values and are not in line with the ideological values of the Indonesian nation so that the government in Indonesia sometimes limits the activities of political parties which can endanger the unity and unity of the Indonesian nation.

The Government of the Republic of Indonesia provides its own space for its people to be involved in political parties or become part of political parties for the sake of creating democracy in Indonesia. Religion can be considered as control over the movements of political parties if it is still in line with the ideology adopted by 
the Indonesian nation, namely the Pancasila ideology. The idea of Islam and politics in Indonesia is very much in accordance with the thoughts of the first President of the Republic of Indonesia, namely Soekarno as the founder of the Indonesian nation who believed that the Indonesian nation was a large nation where religion and political parties could be in accordance with the ideology of the Indonesian nation. Soekarno believed that the Indonesian nation was able to carry out the role of political parties in accordance with the religious values contained therein without any deviation from the Pancasila ideology [25].

According to the President of the Republic of Indonesia, Joko Widodo, said that a large nation is a nation that is able to apply the good values of religious values in everyday life including in politics in Indonesia, but not politicizing religion and creating conflicts between religions [4]. Religion can be considered as a protector of society to avoid deviant actions that harm other people and other nations [7]. Politics in Indonesia is known as free and active politics, that is, it can be said that every political party in Indonesia is free to cooperate with other parties in Indonesia and is active in national and international activities and development. In national development, the role of political parties is considered very important to motivate people to cooperate through political participation and apply religious values for the sake of creating peace and a conducive situation [11].

Muhammad Natsir said that the views on religion and politics in Indonesia must prioritize a just, peaceful and democratic political order. Political Islam is a struggle for the establishment of a democratic and pluralist political system in particular for the acceptance of various religions in Indonesia. Clearly, the expression regarding an Islamic State or a non-Islamic State is strongly rejected and can lead to divisions between religious communities in Indonesia [26]. The application of religious values within political parties is one of the steps taken by the government in order to create values of tolerance between religious communities and good cooperation in politics in Indonesia. Political parties can form coalitions between one party and another without having to see the identity of the party but seeing that unity and unity are values that must be maintained by every Indonesian nation.

\section{Conclusion}

Our research shows that the majority of the population in Indonesia is Muslim and applies religious values in their daily life. Regarding Islam and politics in Indonesia, it is very closely related because the Indonesian people, who are mostly Muslims, tend to apply religious values in accordance with the ideology of the Indonesian nation, namely Pancasila. All people in Indonesia can accept any religion and respect another one. These principles are to create a harmonious and tolerant life in the country. The values of the Pancasila ideology are obligatory for political parties in Indonesia and it can be said that the Republic of Indonesia is not an Islamic State but the State that applies Islamic values and various religions can peacefully co-exist for progress and development in Indonesia.

Islamic extremism is highly rejected by all people in Indonesia because it can cause divisions and conflicts between religious communities. Indonesian political 
parties and Indonesian government do not politicize religion in Indonesia. The principles of democracy in Indonesia prioritize individual and group freedom to be able to express themselves through various political activities in Indonesia and get equal justice between various ethnic groups, races, religions and groups without any differences that can harm other people. All societies have equal rights and equality without any deviation that can cause injustice to everyone.

Religious values are permissible and highly recommended in Indonesian politics to protect the morals foundations of the Indonesian people. Religious values help people in everyday life, but all religious practice in Indonesia should be in accordance with the ideology of the Indonesian nation and the ideals of the Indonesian nation itself.

\section{References}

[1] Tulus W. Political Development Critical Reflections on Crisis. Yogyakarta: BIGRAF Publishing; 2011 (In Indon.).

[2] Carillo B. Our Political Goals. Jakarta: Lappanas; 2016 (In Indon.).

[3] Anwar S. Islamic Thought and Action in Indonesia: A Political Study of New Order Muslim Scholars. Jakarta: Paramadina; 2017 (In Indon.).

[4] Askuri \& Joel C.K. An orientation to be a good millennial Muslims: state and the politics of naming in islamizing Java. Indonesian Journal of Islam And Muslim Societies. 2019; 9 (1): 31-55. doi.org/10.18326/ijims.v9i1.31-55.

[5] Haryono A. Behind the Birth of a Nation and Country. Jakarta: UI Press; 2017 (In Indon.).

[6] Imaa M. Al-Islam waushul al-Ahkam li Ali Abd al-Raziq. Bandung: Grafindo Persada; 2014 (In Indon.).

[7] Rahman B. Religion and State in Islam: an analysis of the Sunni Siyasah Fiqh. Contextualization of Islamic Doctrine in History. Jakarta: Paramadina; 2017 (In Indon.).

[8] Wahid A. State and Cultural Struggles. Depok: Desentara; 2001 (In Indon.).

[9] Ma'arif S. Ground Islam. Yogyakarta: Pustaka Pelajar; 2015 (In Indon.).

[10] Miriam B. Fundamentals of Political Science. Jakarta: Gramedia; 2008 (In Indon.).

[11] Suseno F. Political Ethics Basic Moral Principles of Modern State. Jakarta: Gramedia; 2017 (In Indon.).

[12] Creswell J.W. Research design: qualitative, quantitative, and mixed approaches. Yogjakarta: PT Pustaka Pelajar; 2010 (In Indon.).

[13] Moleong L. Qualitative Research Methodology. Bandung: Remaja Rosda Karya; 2013 (In Indon.).

[14] Noer D. Introduction to Political Thought. Jakarta: Rajawali Press; 2010 (In Indon.).

[15] Thahir T. Political, Cultural and Economic Democracy. Jakarta: Paramadina; 2014 (In Indon.).

[16] Firmanzah. Political Party Management. Jakarta: Yayasan Obor Indonesia; 2008 (In Indon.).

[17] Biglari A. Political Equality and The Issue of Citizenship Rights in Contemporary Islamic Thought. Journal of Islamic Political Studies. 2019; 1 (2): 77-102. doi: 10.22081/jips.2019.68396.

[18] Madjid N. Islamic Intellectual Property. Jakarta: Bulan Bintang; 2011 (In Indon.).

[19] Munawir. Scholars and Community Religiosity. Jakarta: Paramadina; 2013 (In Indon.).

[20] Robert W.H. Which Islam? Whose Shariah? Islamization and citizen recognition in contemporary Indonesia. Journal of Religious And Political Practice. 2018; 4 (3). 278-296. doi.org/10.1080/ 20566093.2018.1525897.

[21] Muhammad S.I. \& Nursiha B.A. Islamic Brand: A Conceptual Definition of Brand from Islamic Perspective. Journal of Islamic Studies and Culture. 2016; 4 (2): 59-71. doi: 10.15640/jisc.v4n2a6.

[22] Haris S. Parties, Elections and Parliaments in the Reform Era. Jakarta: Yayasan Pustaka Obor Indonesia; 2014 (In Indon.). 
[23] Yukihiro Y. The effects of bureaucracy on political accountability and electoral selection. Journal Elsevier/European Journal of Political Economy. 2018; 51 (1): 57-68. doi.org/10.1016/j.ejpoleco.2017.03.009.

[24] Suryadi B. Political Sociology: History, Definition and Development of Concepts. Yogyakarta: IRCiSoD; 2007 (In Indon.).

[25] Boisard M. Humanism in Islam translated by H.M. Rasjidi. Jakarta: Bulan Bintang; 2010 (In Indon.).

[26] Kencana I.S. Introduction to Political Science. Bandung: Pustaka Reka Cipta; 2009 (In Indon.).

\section{Information about the authors:}

Refly Setiawan - Master's Program Student, Department of Political Science, Kazan Federal University, Russia (ORCID ID: 0000-0003-0719-1287) (e-mail: refly@ubl.ac.id).

Melinda Esti - Associate Professor, Department of Public Administration, University of Bandar Lampung, Indonesia (e-mail: estimelinda1987@gmail.com).

Viktor V. Sidorov - Associate Professor, Department of Political Science, Kazan Federal University, Russia (ORCID ID: 0000-0002-6585-5312) (e-mail: viktor.sidorov@kpfu.ru).

\section{Информация об авторах:}

Сетиаван Рефли - студент магистратуры кафедры политологии Института социально-философских наук и массовых коммуникаций Казанского федерального университета (ORCID ID: 0000-0003-0719-1287) (e-mail: refly@ubl.ac.id).

Эсти Мелинда - доцент департамента публичного администрирования Университета Бандар Лампунг, Индонезия (e-mail: estimelinda1987@gmail.com).

Сидоров Виктор Владимирович - кандидат политических наук, доцент кафедры политологии Института социально-философских наук и массовых коммуникаций Казанского федерального университета (ORCID ID: 0000-0002-6585-5312) (e-mail: viktor.sidorov@kpfu.ru). 